\title{
中国農村に打ける社会問題の構造
}

一改革開放後の上海近郊農村の事例一

$$
\text { 王振 }
$$

\section{The Structure of Social Problems in Rural China:}

\section{A Case of Shanghai's Suburban Rural after Reform}

\author{
Wang Zhen (Kyoto University)
}

Chinese rapid economic development has make its suburban rural become richer than its other rural areaes since 1980's. However, changes of rural societies and differentiation of the peasant start with the introduction of market economy and the the function of village governing peasants decreases with the disintegration of People's Community. The money worship reduce supervision to basic-level cadre in these areaes. Therefore, various social problems have also been produced in the developed rural.

The purpose of this paper is to analyse the structure of social problems in rural china and its background with an example of Shanghai's surburb rural in the process of economic development, its results are as follow: (1) in all social problems, the first important social problem to effect the daily living of peasants is the deterioration of social order, and the second is gamblem. (2) The stealing crimes fastly increase with rapid economic development, especially, the stealing crimes increase further with increasing of peasants working away from the less developed rural areaes. (3) The civil disputes in the rural have mainly concentrated on the troubles on house land ownership between peasant families. (4) In recent years, the relationship between cadres and peasants becomes more antagonistic.

\section{1. 課題と方法}

1978年以降の改革開放や経済の高度成長に伴って, 中国の農村社会は質的に大きく転換した．要約すれ ば，その転換は以下の三方面で顕著に現れている．第 1 に，農業の生産責任制の実施によって，農民に経営 の自主権が与えられ，その経済活動ないし非経済活動 が以前に比較しかなり自由になったこと，第 2 に，人 民公社の解体によって，元人民公社の末端の組織であ った生産隊, 現在の村民小組の行政機能が大幅に衰退 し，郷（鎮）・村政府が農民を管理する能力が低下し たこと，第 3 に, 市場メカニズムの導入および経斉の 高度成長により所得格差が扗大し, 農民の階層分化が 著しく進行したこと，である。

このような社会経済の大転換期に㧍いて，農民の生 活水準自体は著しく向上したが，一方で人民公社時代 には存在しなかったさまざまな社会問題が生じ, 1980 年代後半から一層深刻化している. それらは, (1)所得 格差の拡大や人口の流動によってもたらされた強奪, 窃盗などの刑事犯罪の増加, (2)財産, 宅地, 債務, 婚 姻などに係る民事紛争の増加, (3)地方行政権力の過渡

の集中と幹部の不正行為によって引き起こされた幹部 ・農民間の対立，といら三つの点に要約することができ る.

本稿は, 上海近郊の奉賢県青村郷唐家村における 5 村民小組222戸の農家を対象したアンケート調查と聞 き取り調査をもとに, あわせて他の上海近郊農村の関 係資料も参考にして, 経済発展に伴って出現した農村 社会問題およびその生成背景を分析するるのである. 唐家村は上海中心部から南方面へ直線距離で約 54 キロ に位置する． 1 戸当たり・1 人当たりの耕地面積はそ れぞれ 0.201 ha, 0.074 ha と,「蘇南モデル」の一般 的特徵をそなえている．調査対象は，唐家村の第 1 村 民小組（48戸)，第 5 村民小組（53戸)，第 8 村民小組 (51戸)，第10村民小組 (24戸)，第11村民小組 (46戸) の222戸である1). アンケート調査の回答者 222 人の5 ち, 男性が 132 人, 女性が 90 人である。 また, 年龄構 成は 25 歳以下は 7 人，26-40歳層は 102 人，41-50歳層

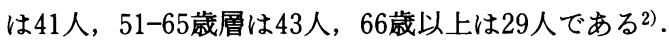
調査農家の 1 戸当たりの家族成員数・労働力数はそれ ぞれ 2.96 人・ 2.12 人である. 農家労働力の農外就業は 1970年代初期から本格的に変化し始めた．222戸の農 
家に拈ける農外就業者数の就業者全体に占める比率 は，1979年の $43.3 \%$ (182人) から，1983年の $52.4 \%$ (236人), 1989年の $84.8 \%$ (397人) へと増加した. しかし1990年に入って，郷鎮企業が急速な成長期から 不安定期に移行したことに伴い, 農外就業者の帰農が 増加し，1994年には農外就業者は $81.4 \%$ (301人）と なっている。

本稿の構成は以下のと招りである. まず第 2 節で は, アンケート調査の結果に基づき農民が農村の各種 の社会問題についてどの程度認識されているかを明か にする. 第 3 節では, 文献資料とアンケート調査の分 析から明らかになった刑事犯罪の深刻化といら事実に より農村治安の現状とその変化を明らかにする. 第 4 節では, アンヶート調査の結果と聞き取り調查資料に 基づき，改革開放政策以降，農民の日常生活に大きな 影響を与えている民事紛争の内容及びその背景を明ら かにする．第 5 節では，アンケート調査の結果から幹 部と農民間の対立についての深刻化の程度とその背景 について分析する．第 6 節は全体の要約である.

\section{2 . 農民の眼でみた農村社会諸問題}

本節では, アンヶート調査表中の「現在農村で最も 主要な社会問題は何か」といら質問に対する農民の回 答について考察する．農村の主要な社会問題を社会風 紀の悪化, 賭博, 刑事犯罪, 民事紛争, 幹部（行政権 力）と農民間の対立，とい55種類に分類した。

社会風紀の悪化は「向銭看」(拝金主義)，「人情風」 (冠婚葬祭などの親戚・友人間のつきあいや贈答の高 額化), 「高消費」(享楽主義), 「開後門」(公権乱用) といった社会風潮を指す。幹部が権力を利用して，家 族及び親族に一般農家の手に入らない生産手段, 生活 手段, および儲けの多い商売や下請けのチャンスを提 供することを「開後門」と呼んでいる，近年，内陸農 村や華南農村では, 宗族の再組織化が進行しており， 土地, 水利のための宗族間の紛争, 末端政権との対抗 さえ出現しているよらであるが3)，本稿で扱ら上海近 郊農村ではこのような事例はほとんど見られない。

賭博では麻雀がその代表である．農村での文化活動 施設が非常に少ないことから, 麻街は農民, とりわけ 青年農民の主要な娛楽活動となっている．しかし麻雀 は常に強い賭博色を持っているので，「6害」の一つ として，政府の取締り項目に入れられている4).

都市近郊農村における刑事犯罪は，当地農民による 刑事犯罪と出稼ざ農民による刑事犯罪に大別される. 都市と比較して, 近郊農村の刑事犯罪の内容は単純で
あり, 農家財産や集団財産の窃盗・強奪, 報復のため の殺人・傷害・財産破壊などが中心である．犯罪の手 段はより直接的かつ非組織的である．婦女子誘拐のよ らな組織的犯罪は上海近郊農村ではほとんどない。

中国では, 家族関係や住宅建築・水利灌溉・債務 婚姻などの民事紛争は，社会不安定要素の一つと見ら れている. 改革開放以来, 農家の個別経済利益に対す る意識が高まり，農家の財産が増加するにつれて，民 事紛争といら農家家族内・農家間のいわゆる「人民内 部矛盾」が，主に財産面に関する利害衝突に多く現れ てきた．民事紛争の調停は村民委員会の調停委員会と 組織外の調停人によって主に行わ机ている.

幹部之農民間の対立の多〈は，農村の「基層幹部」 （郷村行政幹部之郷鎮企業幹部）が，官僚集団の利益 や幹部個人の利益を追求するため, 農民の利益を儀牲 にすることから生じている．農民の参政・監督制度の 整備が十分ではない現状では，土地の集団所有制度や 郷村営企業資産の集団所有制度は，基層幹部の不正行 為を助長しやすい，経済の発展した農村では，農民が 一部の幹部を車, 食卓, ダンスの四脚を指す「四脚の 幹部」と呼んでいるが，発展途上地域では，農民は一 部の幹部を糧, 銭, 命の「三要幹部」と呼んでいる5

さて，農村の社会問題の深刻化を農民自身はどら見 ているのであろらか．表 1 は回答者を 25 歳以下，2640歳，41-50歳，51-60歳，66歳以上と五段階に分類 し，各年龄層の回答を集計したものである．222人の 5ち，当該問題の回答者数は206人である. 206人の5 ち58人 ( $28.2 \%)$ が「よく分からない」と答えたため, 有効回答者数は 148 人である.「よく分からない」とい 万回答が多くなった理由は，急速な社会变容に対して 一部の農民は社会認識や判断が依然として伝統的, 閉 鎖的段階に留まっており，あるいは各種の社会問題に 対して何が最も主要なるのかを自己に関連づけて判断 できないためと考兄られる，年跲層から見ると，「ょ く分からない」と答えた者で，51歳以上の年龄層が最 多である.

表 1 から得られる結論として, 第 1 に, 「社会風紀 の悪化」(53人， $35.8 \%)$ を最も主要な農村社会問題 と考えられており，続いて「賭博」(45人，30.4\%)， 「幹部と農民との対立」(15人，10.1\%)，「刑事犯罪」 (12人， $8.1 \%)$ ，「民事紛争」(10人，6.8\%）となっ ている.「その他」と答えた者は13人であり，その内 容は「迷信活動」(11人) と「物価の上昇」（1人)，「若 者が老人を尊敬していない」(1人) であった ${ }^{6)}$.

第 2 に，年龄層により農村の社会問題に対する認識 
表 1 .「現在農村での最も主要な社会問題は何か」に関するアンケート調査の集計

\begin{tabular}{|c|c|c|c|c|c|c|c|}
\hline 年 战 別 & 社会風紀 & 賭 博 & 刑事犯罪 & 民事紛争 & $\begin{array}{l}\text { 幹部と曹民 } \\
\text { との対立 }\end{array}$ & その他 & 合 計 \\
\hline 25歳以下 & $\begin{array}{c}2 \\
(33.3)\end{array}$ & $\begin{array}{c}0 \\
(0.0)\end{array}$ & $\begin{array}{c}2 \\
(33.3)\end{array}$ & $\begin{array}{c}0 \\
(0.0)\end{array}$ & $\begin{array}{c}1 \\
(16.7)\end{array}$ & $\begin{array}{c}1 \\
(16.7)\end{array}$ & $\begin{array}{c}6 \\
(100.0)\end{array}$ \\
\hline 26-40歳 & $\begin{array}{c}30 \\
(41.7)\end{array}$ & $\begin{array}{c}18 \\
(25.0)\end{array}$ & $\begin{array}{c}5 \\
(6.9)\end{array}$ & $\begin{array}{c}5 \\
(6.9)\end{array}$ & $\begin{array}{c}8 \\
(11.1)\end{array}$ & $\begin{array}{c}6 \\
(8.3)\end{array}$ & $\begin{array}{c}72 \\
(100.0)\end{array}$ \\
\hline 41-50歳 & $\begin{array}{c}11 \\
(36.7)\end{array}$ & $\begin{array}{c}13 \\
(43.3)\end{array}$ & $\begin{array}{c}1 \\
(3.3)\end{array}$ & $\begin{array}{c}1 \\
(3.3)\end{array}$ & $\begin{array}{c}2 \\
(6.7)\end{array}$ & $\begin{array}{c}2 \\
(6.7)\end{array}$ & $\begin{array}{c}30 \\
(100.0)\end{array}$ \\
\hline 51-65歳 & $\begin{array}{c}7 \\
(29.2)\end{array}$ & $\begin{array}{c}9 \\
(37.5)\end{array}$ & $\begin{array}{c}3 \\
(12.5)\end{array}$ & $\begin{array}{c}2 \\
(8.3)\end{array}$ & $\begin{array}{c}1 \\
(4.2)\end{array}$ & $\begin{array}{c}2 \\
(8.3)\end{array}$ & $\begin{array}{c}24 \\
(100.0)\end{array}$ \\
\hline 66歳以上 & $\begin{array}{c}3 \\
(18.8)\end{array}$ & $\begin{array}{c}5 \\
(31.3)\end{array}$ & $\begin{array}{c}1 \\
(6.3)\end{array}$ & $\begin{array}{c}5 \\
(12.5)\end{array}$ & $\begin{array}{c}3 \\
(18.8)\end{array}$ & $\begin{array}{c}2 \\
(12.6)\end{array}$ & $\begin{array}{c}16 \\
(100.0)\end{array}$ \\
\hline 合 計 & $\begin{array}{c}53 \\
(35.8)\end{array}$ & $\begin{array}{c}45 \\
(30.4)\end{array}$ & $\begin{array}{c}12 \\
(8.1)\end{array}$ & $\begin{array}{c}10 \\
(6.8)\end{array}$ & $\begin{array}{c}15 \\
(10.1)\end{array}$ & $\begin{array}{c}13 \\
(8.8)\end{array}$ & $\begin{array}{c}148 \\
(100.0)\end{array}$ \\
\hline
\end{tabular}

出所 : 唐家村 222 戸の農家に対するアンケート調査資料より作成。

注：（）は\%．当該問題の回答者は206人である.その5ち58人は「ょく分からない」と答えた．206人の5ち，25歳以下は 7 人， $26-40$ 歳は 97 人，41-50歳は 41 人，51-65歳は 34 人，66歳以上は 27 人である.

が異なることも重要である.41歳以上層では「賭博」

（38.6\%）を最も主要な社会問題と考えており，「社 会風紀の悪化」(30.0\%) より8.6ポイントも上回って いる. 続いて「民事紛争」(11.4\%)，「幹部と農民と の対立」(8.6\%)，「刑事犯罪」(7.1\%) となっている. 40 歳以下の層では「社会風紀の悪化」(41.0\%) を最 大の社会問題と考えて拔り，「賭博」(23.1\%) を大き く引き離している．続いて「幹部と農民との対立」 $(11.5 \%)$ ，「刑事犯罪」(9.0\%)，「民事紛争」(6.4\%) となっている.このような認識の格差が生した理由と して，相対的に高い教育を受けた 40 歳以下の者につい ては村外での活動が多く，外部の情報にもよく通じて いることから，より広い視野で農村の社会問題を認識 できることにあると考えられる. 反対に，41歳以上の 者は, 村内の現状とその変化でしか社会の変化を判断 できていない可能性がある．ところで，25歳以下の若 年層で「賭博」と答えた者は一人もいない. 若者の多 くにとって麻雀等の「賭博」は余啹の過ごし方の一つ であって，「賭博」は社会問題とは考えられていない，

第 3 に, 農民の認識が政府, 学者, マスコミのそれ と大差があることも重要である. 多くの場合, 後者が 注意を払らのは「刑事犯罪」や「幹部と農民との対立」,

「民事紛争」である.なぜなら，これらの問題は農家 - 集団・国家とい5三者の利益を直接的に損い，社会秩 序の破壊や不安定を引き起こしやすい要因であるから である。一方,「社会風紀の悪化」,「賭博」「迷信」 はよくない社会現象であっても，一気に重大な社会問 題として現れないからである．ところが，農民の関心 は往々に自己の利益や日常生活と緊密な関係にある. 例之ば，冠婚葬祭などの親戚・友人間のつきあいや賆
答の高額化, 所得の不公平, 人間関係の金銭化といっ た「社会風紀の覀化」等は, 農村社会の伝統なモラル を破壊するとともに，多くの農民の利益を直接的に損 らのである.ささらに,「賭博」に起因した強奪, 窃盗, 離婚が農村でよく見られるが，それ以外にも麻雀等の 「賭博」活動に多くの時間を費すことで, 農家の生活 秩序や生産条件が擳乱される傾向にあることは，大き な問題となっている.

\section{3. 刑事犯罪と農村の社会治安}

所得格差の拡大, 政府の社会統制能力の弱体化, おo よび内地からの大量の出稼ぎ農民といった新たな社会 環境に扣いて, 上海近郊農村の社会治安はどのように 変化したのであろらか. 本節では, アンケート調査資 料にくわえ, 奉賢県や近隣の南匯県・元川沙県（現在 浦東新区）の関係資料に基づいて，唐家村及びその周 辺の農村の社会治安状況を考察する.

\section{(1) 経済成長と農村の社会治安}

周知のよ5に, 経済の急成長が社会治安に深刻な影 響をもたらすのは，多くの発展途上国で一般に見られ る現象である．それは中国農村においても同じであ る. 以下に唐家村が所属する奉賢県の全体の概況を述 べる.

他の沿海地域と同様, 1978年以降奉賢県の経済は, 経済引締め期（1985-86年，1989-91年）を除き，高ス ピードで成長してきた，例えば，工農業総生産額の対 前年の実質伸び率は，1984年は $23.8 \% ， 1988$ 年は 32.1 \%，1992年は $31.5 \% ， 1993$ 年は $40.0 \%$ であった7)．と ころが，同時に農村の社会治安問題も深刻化してき た. 刑事犯罪は社会治安状況を映す鏡である. 奉賢県 
法院で受理した刑事案件は，1985年の153件から1990 年の 250 件，1994年の334件へと約 2 倍に增加した. 特 に，1989年や1993-94年には農村の治安悪化が目立っ ている. 1989年に受理した刑事案件は247件に達し, 1988年より 76.4\%上昇した．1993年に受理した刑事案 件は242件，1992年より $39.1 \%$ も增加し，1994年の32. 7\%へと增加し続けた ${ }^{8)}$.

各種の刑事犯罪のらち，農村の社会治安に最大の影 響を与えたのは窃盗である。表 2 はアンケート調査表 の「本村での最も主要な刑事犯罪は何か」といら問い に対する135人の回答を集計したものである．135人の 約 9 割にあたる121人の回答者が「窃盗」を農村刑事 犯罪の最も重大なものと考えていることが分かる．村 民小組別に見ても，同様の順位となった.

\section{（2）上海近郊㷧村における刑事犯罪の特徵}

1990年代に入ってから，上海近郊農村に括ける刑事 犯罪には，新たな特徵が見らけられる．窃盗犯罪, 経 済犯罪が特に多くなり，また出稼ぎ農民による窃盗犯 罪も深刻化しているといら点である.

表 3 に, 奉賢県の東に接する南匯県の刑事犯罪状況 を示す. 1994年に県法院で受理された刑事案件数は 332件であった，そのらち，202件 (60.8\%) は「窃盗 犯罪」であり，58件（17.5\%）は「経済犯罪」であっ

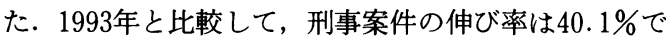

あったが，「窃盗犯罪」は47.5\%，「経済犯罪」は286。 7\%となっている. 1994年に判決を下された 556 人の犯 罪者のらち，「窃盗犯罪者」は349人 $(62.8 \%)$, 経済 犯罪者は65人（11.7\%）であった，さらに窃盗犯罪者 を見ると，「出稼ぎ農民」が171人（49.1\%）で1993年 より $56.9 \%$ も増加したが，「本地人」も 178 人（50. 9\%)，1993年より $78.0 \%$ 急増した。

実際に，法院，検査院で受理した案件は刑事案件総 数中の起訴された案件に過ぎない，多くの案件は留 置, 罰金等の形で公安機関によって処理されている. 南匯県の場合, 実際の刑事案件が1993年に 740 件, 1994年に962件起こっており，その中の 8 割が窃盗案 件であった . 近郊農村の社会治安に大きな影響を及 ぼす賭博は,「治安案件」として公安機関でも処理さ れている. 南匯県を例にとれば, 1994年に公安機関で 処理した賭博案件は 201 件, 賭博人数は 931 人に登っ た. そのうち，10万元以上の賭博案件が 2 件あった ${ }^{10)}$.

窃盗犯罪が急速に増加した社会背景としては，前述 した「社会風紀の悪化」, 後述する出稼ぎ農民の増加 のほか，郷鎮企業の経営不振による帰農者の増加，農 村内部の富裕層々貧困層の両極分化, 元生産隊の行政 機能の解体と官僚腐敗による政府の社会統制能力の弱 体化などがあげられる。ここで特筆すべきは，郷鎮企 業の経営不振による帰農者の増加である．唐家村の例

表 2.「本村での最も主要な刑事犯罪は何か」に関するアンケート調査の集計

単位: 人

\begin{tabular}{|c|c|c|c|c|c|c|}
\hline 村民小組別 & 窃 盗 & 横領收賄 & $\begin{array}{ll}\text { 賭 博 } \\
\end{array}$ & 詐 欺 & な & 合 計 \\
\hline $\begin{array}{ll}\text { 第 } & 1\end{array}$ & 25 & 1 & 2 & & & 28 \\
\hline 第 5 & 32 & 1 & & & 2 & 35 \\
\hline 第 8 & 28 & 1 & & & 1 & 30 \\
\hline 第 10 & 13 & 1 & & 1 & & 15 \\
\hline 第 $\quad 11$ & 22 & 1 & 1 & & 1 & 25 \\
\hline 計 & 121 & 5 & 3 & 1 & 4 & 135 \\
\hline
\end{tabular}

出所 : 表 1 と同じ.

注 : 回答率は $59.9 \%$ である.

表 3．南龨県に括ける刑事犯罪

単位 : 件, 人

\begin{tabular}{|c|c|c|c|c|c|c|c|}
\hline \multirow{3}{*}{ 年 度 } & \multirow{3}{*}{ 刑事案件数 } & \multirow{3}{*}{ 犯罪者数 } & \multicolumn{5}{|c|}{ 内 訳 } \\
\hline & & & \multicolumn{3}{|c|}{ 窃盗犯 罪 } & \multicolumn{2}{|c|}{ 経 済犯 罪 } \\
\hline & & & 案件数 & 犯罪者数 & 内 : 外来者 & 案件数 & 犯罪者数 \\
\hline 1993 & 237 & 367 & $\begin{array}{c}137 \\
(60.8)\end{array}$ & $\begin{array}{c}209 \\
(62.8)\end{array}$ & 109 & $\begin{array}{l}15 \\
(6.3)\end{array}$ & $\begin{array}{l}15 \\
(4.1)\end{array}$ \\
\hline 1994 & 332 & 556 & $\begin{array}{c}202 \\
(57.8)\end{array}$ & $\begin{array}{c}349 \\
(57.0)\end{array}$ & 171 & $\begin{array}{c}58 \\
(17.5)\end{array}$ & $\begin{array}{c}65 \\
(11.7)\end{array}$ \\
\hline 前年比（\%) & 40.1 & 51.5 & 47.5 & 67.0 & 56.9 & 286.7 & 333.3 \\
\hline
\end{tabular}

出所 : 南匯県人民代表大会の工作報告（1995年）より作成.

注：（）は\%。.ここでの刑事犯罪件数は人民法院で受理したものである. 
では，村営企業は1989年から経営不振に陥ってきた。 その純利潤額は1988年の 90.87 万元から連続して低下 し，1992年にはマイナスの130.34万元となった. 1994 年においてもマイナス 3.16 万元と依然として経営不振 の状況にあった．村営企業の雇用者数も1988年の 448 人から，1992年の 179 人，1994年の 115 人へと大幅に減 少している11)．失業者の一部が郷営企業に転職し，一 部が帰農した．郷営企業からの帰農者を加えて，唐家 村の農業従事者は1991年に最低の62人から，1993年に 99 人，1994年に 234 人へと急増した。しかし，これら の帰農者は「閑散労働力」とも呼ばれている．なぜな ら，多くの帰農者が依然として高給を求め，農業生産 に専従することなく，家で閑散したり，臨時工として 職を求めたり，新しいチャンスを探しているからであ る. 窃盗犯罪の深刻化は一定程度これらの実情と関係 があるものと考えられる。

\section{（3）出稼ぎ農民の刑事犯罪}

上海近郊農村に拈ける郷鎮企業の急速な発展によ り，内陸農村からの出稼ざ農民が激増している．例え ば，1993年に他地域から流入した出稼ぎ労働力総数と それが本地域労働力総数に占める割合は, 奉賢県全体 では 16468 人 (6.9\%)，青村郷は408人（3.0\%），唐家 村は37人（3.9\%）であった12)。これらの出稼ぎ農民 は上海近郊農村の経済発展の原動力として無視できな い.しかし一方で，農村の社会治安維持に大きな負担 となっている. 例えば, 奉賢県の東北へ, 南匯県の北 接する元川沙県（現在浦東新区）への流入者数は 1987 年の 13,900 人から 1989 年の 35,000 人へと $151.8 \%$ 増加 し，流入者中の窃盗犯罪者も31人から 126 人へと 306.4 \%増加した ${ }^{13)}$. 南匯県への流入者数も1993年の 13,159 人から 1994 年の 14,839 人へと $12.8 \%$ 増加し, 流入者中 の窃盗犯罪者は 109 人から 171 人へと $56.9 \%$ 増加した ${ }^{14)}$.

窃盗犯罪者の出身地は, 表 4 に見られるよらに江 蘇, 浙江, 安徽等の近隣省と四川省等の内陸に集中し

表 4. 川沙県に打ける外来窃盗犯罪者の出身地と戸籍 -1989年の126名の犯罪者調査

\begin{tabular}{cc|c|c|c}
\hline \hline 省 & 別 & 人 数 & 構 成 比 & 農民の割合 \\
\hline 江 & 蘇 & 47 & 37.3 & 100.0 \\
安 & 徽 & 48 & 38.1 & 100.0 \\
四 川 & 16 & 12.7 & 100.0 \\
浙 & 江 & 13 & 10.3 & 100.0 \\
貴 & 州 & 1 & 0.8 & 100.0 \\
山 東 & 1 & 0.8 & 100.0 \\
\hline 合 計 & 126 & 100.0 & 100.0 \\
\hline
\end{tabular}

出所 : 沙松「外地来㵧人員窃盗犯罪的特点分析」 (『社会』1990年第10期）p. 11 .
ており，その身分は全て農民である. 主要な窃盗品と しては，建築工事や工場の原材料であり，その件数は $54.6 \%$ を占めている．他には現金・金品（13.9\%）, 自転車・バイク $(8.4 \%)$, 電器 $(7.9 \%)$ が主なもの である15).

上海近郊農村は「浦東開発」の利益を大いに受ける 一方, 社会治安の悪化といら代価を支払っている. 1990年代に入ってから，多くの出稼ぎ農民がチャンス を求め上海に移入してきている. また，近郊農村では 臨時工が不足していることから農村部への流入も多 い. しかし，出稼ぎ農民の急速な流入に対して，近郊 農村は一時的な労働力の需給バランスを確保できな い. 例えば, 郷鎮企業が不安定成長期に転入し，その 労働力需給がマイナスへと転じて, 多くの失業者を発 生させる結果となった. 上海近郊農村に拉ける郷鎮企 業の労働力雇用は1988年に最高の 171.06 万人となった 後, 連続しで減少し, 1993年には147.16万人まで減少 した ${ }^{16)}$. その結果, 流入農民の多くが常に失業・休業 に追い込まれるといった不安定な状態が続出してい る. その一方で，多くの出稼ぎ農民は金を稼いで故郷 に帰り, 家を建てるという夢を持って扣り, 彼らは欲 求が満たされないと, 手っ取り早く稼げる方法を安易 に選択していると考察される.

\section{（4）幹部の経済犯罪}

鄉鎮企業幹部, 農村行政幹部を中心とした経済犯罪 も増加している. 表 5 は南匯県検察院で受理された経 済犯罪者数の推移を示したものである. 犯罪者数だけ から見ると, 犯罪案件が減少の傾向にあるように見ら れる. しかし実際には, 受理の基準が引き上げられて いるので，引き上げ前に受理された案件が小案件とし てもれ落ちていると考えられる. 表 5 が示すように, 検察院の受理基準は1989年には2,000-3,000元にすぎ なかったが，1991年に 1 万元，1993年に 1 万元以上へ と移行した。言い換えれば，1989年以前の登録基準を

表 5 . 南匯県に打ける経済犯罪者数の推移

\begin{tabular}{c|c|c|c}
\hline \hline 年 度 & 犯罪者数 & 受理の標準 & $\begin{array}{l}\text { 附 }: \text { 農村労働力 } \\
\text { 当たりの年所得 }\end{array}$ \\
\hline 1989年 & 105 人 & $2,000 \sim 3,000$ 元 & 2,050 \\
1990年 & 100 人左右 & 同上 & 2,261 \\
1991年 & 80 人余 & 1 万元以下 & 2,628 \\
1992 年 & 70 人余 & 同上 & 2,638 \\
1993 年 & 50 人余 & 1 万元以上 & 3,111 \\
1994 年 & 64 人 & 同上 & 3,995 \\
\hline
\end{tabular}

出所 : 南龨県人民検察院の公告欗より作成.

注 : ここでの経済犯罪者数は検察院で受理されたもので ある. 
用いて1993年の経済犯罪者数を推計すれば，その人数 は表 5 に示された登録者数をはるかに超えることにな る.

1994年の状況を見ると，南陮県検察機関で受理した 経済案件が 61 件，前年比 $35.6 \%$ の伸びである. その特 徵は以下のように整理でさる，第 1 に横領，収賄が圧 倒的に多い（横領が13件, 収賄が43件). 第 2 に横領, 収賄 5 万元以上の大事件も多く見られる -(17件)，第 3 に末端経済管理部門の幹部の横領, 収賄案が一定の 割合を占めている (10件). 第 4 に経済犯罪案件が発 生した主要な部門は建築業である（42件）。第 5 に64 人の経済犯罪者中, 工場長・経理等の郷鎮企業幹部が 50 人に近く，91\%を占めている17).

郷鎮企業幹部，農村行政幹部の経済犯罪によっても たらされる最大の害悪として，国家財産，集団財産， 農民利益の着服以上に, 農村の治安不安定の誘発要素 になることがあげられる．農民の行動に対する村党支 部や村民委員会の統制機能が失われた現在, 多くの農 民が郷鎮企業に就労しているので, 郷鎮企業が次第に 農民の行動を統制する新たな組織となりつつある．し かし，集団企業を主体とする上海近郊農村では，企業 幹部自身の横領, 収賄などの不法行為が, 企業資産所 有者である農民の収入不公平に対する不満を激化さ せ, かつ企業経営の悪化の一つの要因となり, さらに 農民の就労の安定性も害している. 一方, 特定の地域 や部門の企業上部管理部門の党・政府・本社の指導者 は地方政府・企業の利益のために企業幹部の不法行為 を容認したり，自分たちの管理・監督面の欠陥を暴露 させることを嫌がり，さらには自分自身も収賄してい る等の理由で,それらの経済犯罪を党規や行政規律違 反等で簡単に処理している，その結果，農民の不満が 個別の企業幹部から農村の党・政部門に移転し，さら に深刻な社会矛盾を引き起こし始めているのである.

\section{4 . 農村の民事紛争}

農村の民事紛争には, 主に家庭内の紛争や財産継承 紛争・農家間の宅地紛争・債務紛争および離婚があげ られる．人民公社時代と比較すれば，1980年代初め以 来, 商品経済の全面的な導入および中央集権体制の解 体につれて，農村の民事紛争も新な様相を呈してい る. 一つは債務, 財産, 婚姻, 賭博等に関する紛争が 多くなり, そのうち多くが経済利益と直接的に関連し ている．も5一つは年龄層別に見ていくと，従来の高 龄層や中年層を主とした紛争から現在の中年層や若年 層を主とした紛争への変化が見られる ${ }^{18)}$. 唐家村でる
家庭内の紛争，財産継承紛争，農家間の宅地紛争およ び離婚が生じている，そこで，本節では各種の民事紛 争とその原因を考察する.

\section{（1）民事紛争の種類と程度}

表 6 は,アンケート調査表の「現在本村で最も主要 な民事紛争は何か」といら問いに対する123人の回答 を村民小組別に集計したものである．191人から回答 を得たが，68人が「よく分からない」と答えた．有効 回答数 123 人の5ち「宅地紛争」と答えた人は78人 (63. $4 \%)$ で，「離婚」が23人 $(18.7 \%)$ ，「家庭問題」（家 庭内の紛争と財産継承紛争を指寸) が14人（11.4\%)， 「その他」が 8 人 (6.5\%) であった．以上から，唐 家村の最も主要な民事紛争は「宅地紛争」であるとい らことが分かる.「その他」と答えた人のらち，4人 は「債務紛争」，3人が「近隣紛争」，1人が「耕地紛 争」となっている.

村民小組別にみると，「宅地紛争」が全ての村民小 組で最も主要な民事紛争である.「宅地紛争」の比率 は第 1 組で $50.0 \%$ ，第 5 組 $65.6 \%$ ，第 8 組 $46.2 \%$ ，第 10 組 $75.0 \%$ ，第 11 組 $80.8 \%$ であり，第10組と第 11 組に おける「宅地紛争」は他の村民小組より深刻である. 第 1 組と第 5 組・第 10 組では「離婚」の方が「家庭問 題」より深刻である．第11組では「家庭問題」が最も 深刻である．第 8 組では，「家庭問題」と答えた者 6 人 $(23.1 \%)$ は「離婚」 6 人 $(23.1 \%)$ と同じである.

\section{(2)「宅地紛争」}

「宅地紛争」が農村の主要な社会問題となったのは, 1970年代末以降の農村住宅建設ブームと関係がある. 周知のよ5に，中国農民は所得が上昇すれば，その所 得を優先に住宅新築や改築に投資する傾向にある.

表 6.「現在本村での最も主要な民事紛争は何か」に 関するアンケート調査の村民小組別集計

単位 : 人, $\%$

\begin{tabular}{c|c|c|c|c|c}
\hline \hline 組別 & 家庭問題 & 宅地紛争 & 離 婚 & その他 & 合 計 \\
\hline 第1 & 3 & 12 & 6 & 3 & 24 \\
& $(12.5)$ & $(50.0)$ & $(25.0)$ & $(12.5)$ & $(100.0)$ \\
第 5 & 2 & 21 & 8 & 1 & 32 \\
& $(6.3)$ & $(65.6)$ & $(25.0)$ & $(3.1)$ & $(100.0)$ \\
第8 & 6 & 12 & 6 & 2 & 26 \\
& $(23.1)$ & $(46.2)$ & $(23.1)$ & $(7.7)$ & $(100.0)$ \\
第10 & 1 & 12 & 2 & 1 & 16 \\
第11 & $(6.3)$ & $(75.0)$ & $(12.5)$ & $(6.3)$ & $(100.0)$ \\
\hline 合計 & $(11.1)$ & $(80.8)$ & $(3.8)$ & $(3.8)$ & $(100.0)$ \\
\hline
\end{tabular}

出所 : 表 1 と同じ.

注：（）は\%．当該問題の回答者者は191人である。 そのらち67人が「よく分からない」と答えた。 
1978年以降，農産物価格の上昇や農業生産責任制導入 後の農業所得增, 農家の兼業化により, 農家所得が增 大し, 積極的に住宅投資が行われた. 表 7 は, 唐家村 5 村民小組に和ける1979-88年の住宅建設状況を示し たものである. 1979年-88年の10年間に167戸の農家が 約 2.33 万 $\mathrm{m}^{2}$ の住宅を新築・改筑し, 1 戸当りの居住面 積は $140 \mathrm{~m}^{2}$ となった. 1988年までに新築・改築を行わ なかった農家は12戸しか存在しない。その内訳は第 1 組は 1 戸，第 5 組は 3 戸，第 8 組は 6 戸，第 10 組は 2 戸である．多くの高龄者は独立の戸籍を持っていた ク, 生活に执いては一人で食事をしていたりするが, 多くは同居であるため実際の調査戸数は179戸であっ た.この点を加味すると, 住宅条件を改善しなかった 農家は6.7\%に過ざなかった。

上海近郊農村の宅地とは, 前庭や後庭等の敷地と建 地の両者を含んでいる. 耕地が集団所有であるにもか かわらず, 住宅の新筑・改築の際, 農家の共通の行動 として宅地をできるだけ拡大しようとする．ところ が, 宅地に使用可能な土地が有限であり, 宅地周辺の 土地の使用権がはっきりしていないので, 近隣農家間 で宅地紛争が激化することになったのである．農村社 会制度の変容に伴う農村住宅建設ブームは，人民公社 制度が解体されたにもかかわらず, 市場経済化に対応 する新たな組織や制度がまだ整備されていなかった時 期に起こった. 行政手段を通して土地の下請経営制度 を推進した一方, 土地使用, とりわけ農家自留地の宅 地への転用, 宅地周辺の集団所有土地の使用, 農家間 の境界地(間隔地)等に対する行政管理が弱くなった.

「人治」社会の下, 生産隊から移行した村民小組の経 済機能の弱体化や多くの優秀な農村幹部が郷鎮企業に 移ったために，農村基層組織が民事紛争を調停する機 能も大いに弱まった。 こうして, 農家の利益と直接に
結びつく「宅地紛争」は農村改革の中で発生した最も 主要な民事秎争となり, 最大の社会問題になった.

近代化への転換期において，「宅地紛争」のような 民事紛争の激化は不可避である．改革に適合する組織 と制度の新設が遅れ，民事紛争は一層激化した，とこ ろが，1980年代末以降，農村民事紛争の調停組織の払 大, 土地法の公布,「村規民約」の制定により，宅地 紛争の発生は相対的に緩和に向かっている. 奉賢県統 計局によれば，人民調停委員会が住宅紛争を中心とし た民事紛争（離婚が含をれていない）を調停した件数 は1990年の 2443 件, 1991年の 2,596 件から，1992年の 2,197件，1993年の 1,754 件へと減少している ${ }^{20)}$.この ような傾向は, 改革後の思想解放等を経て, 農民が社 会の急激な変化に慣れたこと，および農村が豊かにな り，農民の許容力も向上したことを意味している.

\section{5. 幹部と農民間の対立}

制度変革および経済の急成長は, 農民と幹部との間 の関係にどのよらな変化をもたらしたのか．本節で は，アンヶート調査に基づき，この点を分析する.

表 8 は「現在農民と村幹部との関係がどらか」とい 5問いに対する201人の回答を集計したものである. 表中の「以前」は集団化時代を指寸，本表から「以前 よりよくなった」と答えた者の比率は $31.3 \% て ゙ あ り ，$ 「変化なし」と答えた者は $24.4 \%$,「以前より悪くな った」と答学た者は $44.3 \%$, 多くの回答者が農民と 村幹部間の関係が以前より悪くなったと考えている. 特に青壮年層（50歳以下，142人）で，「以前上り悪く なった」と答えた者の比率（49.3\%）は，「以前より よくなった」と答えた者のそれ（27.4\%）を大幅に上 回っている.アンケート調査表が村幹部が行き来する 調査場所で農民自身に記入してもらったといら状況を

表 7 ．唐家村 5 村民小組に括ける住宅建設状況（1979～88年）

\begin{tabular}{|c|c|c|c|c|c|c|c|}
\hline \multirow{3}{*}{ 村民小組別 } & \multirow{3}{*}{ 新築農家数 } & \multirow{3}{*}{ 新築面積 } & \multicolumn{4}{|c|}{ 内 訳 } & \multirow{3}{*}{ 未建設農家 } \\
\hline & & & \multicolumn{2}{|c|}{ 1979 83年 } & \multicolumn{2}{|c|}{ 1984 88年 } & \\
\hline & & & 新築農家数 & 新 筑面 積 & 新筑農家数 & 新築面積 & \\
\hline 第 1 & 40 & 5823 & 13 & 1747 & 27 & 4076 & 1 \\
\hline 第 5 & 42 & 6016 & 14 & 1832 & 28 & 4184 & 3 \\
\hline 第 8 & 34 & 4610 & 17 & 1960 & 17 & 2650 & 6 \\
\hline 第10 & 16 & 2214 & 9 & 1412 & 7 & 802 & 2 \\
\hline 第11 & 35 & 4678 & 16 & 2066 & 19 & 2612 & 0 \\
\hline 合 計 & 167 & 23341 & 69 & 9017 & 98 & 14324 & 12 \\
\hline
\end{tabular}

出所 : 222 戸の農家に対する聞き取り調査により作成.

注 : 多くの老人家族は個別の戸籍を持っていたり，食事を個人でしていても，住宅の多くは子供と同居している，末建設農家 数は実際値であり，老人核家族は含まれていない。 
表 8.「現在農民と村幹部との関係はどうか」に関す るアンケート調査の集計

単位: 人. $\%$

\begin{tabular}{c|c|c|c|c}
\hline \hline 年 齢 別 & よくなった & 変化なし & 悪くなった & 合 計 \\
\hline \multirow{2}{*}{40 葴以下 } & 34 & 22 & 49 & 105 \\
& $(32.4)$ & $(21.0)$ & $(46.7)$ & $(100.0)$ \\
$41 〜 50$ 歳 & 5 & 12 & 20 & 37 \\
& $(13.5)$ & $(32.4)$ & $(54.1)$ & $(100.0)$ \\
51 歳以下 & 24 & 15 & 20 & 59 \\
\hline 合 計 & $(40.7)$ & $(25.4)$ & $(33.9)$ & $(100.0)$ \\
\hline
\end{tabular}

出所 : 表 1 と同じ

注：（）は\%。

考虑すれば，一部の回答者が本当は「以前より悪くな った」を考えているものの，実際の回答としては「変 化なし」，ないし「以前よりょくなった」と答えた事 例も予想される，言い換えれば，被調査者のらち，農 民と村幹部間の関係が以前より悪くなったといら考皇 を持っている方の比率は上述した数値より高いものと 考えられる。

上述した農民と幹部間の関係変化はかなりの程度で 幹部自身の変化と関係がある. 表 9 は, 農村基層幹部 への評価に関する回答の集計である. アンヶート調査 表では幹部を「模範となっている」「「仕事はまじめで あるが，個人の利益も図っている」，「官僚主義がひど い」，「権力で集団や民衆に損をさせ私利を図ってい る」といら四つに類別している. 各類別の回答者数 は，それぞれ186人，189人，186人，182人である.

幹部への評価を問ら質問に対しては，厳しい結果が 出ている. 表 9 に見られるよらに，「模範となってい る幹部が極少数，あるいは少数」といら回答は全体の $65.1 \%$,「極多数, 多数」の $20.9 \%$ の 3 倍以上である. 反対に「仕事はまじめであるが，個人の利益む図って いる幹部が極多数，あるいは多数」が $49.7 \%$,「極少 数, あるいは少数」の $33.8 \%$ 五回っている.「官僚
主義がひどい幹部が極多数，あるいは多数」が29. 0\%，「権力で集団や民衆に損をさせ私利を図っている 幹部が極多数, あるいは多数」が $24.7 \%$ と一定の比率 を占めている，同様に，村幹部の被調査者への影響を 考㦄すると，無回答はむしろ消極的評価をしたものと 見なせば，このアンケート調査の結果は，現在の村幹 部に対して，「私利を図っている」とまでは言わない ものの，「仕事はまじめであるが，個人の利益も図っ ている」「模範となっていない」という評価をしてい るものと見ることができよう。

以上から分かるように，現在の農村基層幹部の中に は，「模範となっている」が少数ながらいるものの， 「仕事はまじめであるが，個人の利益も圀っている」 ものが多数を占めている. しかし，「官僚主義がひど い」および「権力で集団と民鼻に損をさせ私利を図っ ている」は少数であった，言い換えれば，個人主義が 台頭したものの，腐敗現象もまだ甚だしくはないと言 える.

現在の農民と幹部の関係は, 建国以来 2 度目の厳し い状況にあると言われている21)，1 度目は1970年代の 「資本主義の尻尾を斬る」といわれた時期である。そ の主要な原因は, 生活改善のための農民の家庭副業を 「資本主義的である」として取り除くといった，農村 の現実や農民の意志に反した「左の路線」にあった.

農民生活が豊かになった現在，農民と幹部間の対立の 深刻は何によるものであろらか.

まず，政策と制度面によるものがあげられる，中央 集権化の進んでいた人民公社時代と比較し，独立した 生産者となった農民は, 個人・集団・国家の三者の利 益分配において個人主義的傾向を持つようになった。 特に多くの労働力が伝統農業から郷鎮企業にシフトし たために，個人利益を保護する民主意識が大いに強化 されることとなった．しかしながら，改革開放後の新 たな農村政策と制度の中で，強制や人治といった行政

表 9 ．農村基層幹部の評価に関するアンケート調査の集計

単位: 人. $\%$

\begin{tabular}{c|c|c|c|c|c|c}
\hline \hline 幹 部 の 類 別 & 極多数 & 多 数 & 半 分 & 少 数 & 極少数 & 合 計 \\
\hline (1)模範となっている幹部 & 9 & 30 & 26 & 55 & 66 & 186 \\
(2)仕事がまじめであるが個人利益 & $(4.8)$ & $(16.1)$ & $(14.0)$ & $(29.6)$ & $(35.5)$ & $(100.0)$ \\
も図っている幹部 & $(18.5)$ & 59 & 31 & 49 & 15 & 189 \\
(3)官僚主義がひどい幹部 & 13 & $41.2)$ & $(16.4)$ & $(25.9)$ & $(7.9)$ & $(100.0)$ \\
& $(7.0)$ & $(22.0)$ & $(15.1)$ & $(30.6)$ & $(25.3)$ & $(100.0)$ \\
(4)権力で集団や民䊩に損をさせ私 & 19 & 26 & 18 & 45 & 74 & 182 \\
利を図っている幹部 & $(10.4)$ & $(14.3)$ & $(9.9)$ & $(24.7)$ & $(40.7)$ & $(100.0)$ \\
\hline
\end{tabular}

出所 : 表 1 と同じ.

注：（）は\%。 
手段の適用も依然としてかなりの割合を占めている. 例之ば，国家が市場価格より安価に食糧を買付ける 「定購糧」政策，郷（鎮）・村が農家から現金を徵収 する「提留款」制度, 拉よび一人子の人口抑制政策等 である.これらの政策や制度が農民の個人的利益と対 立している. 特に一貫性を欠く農業政策や地方政府の 「土政策」(地方政府自身の利益のため制定する中央 政府の政策と異なる政策を指す）が農民と幹部間の矛 盾を一層激化させている．例えば，「売糧難」(食糧が 売れない）には「徵購制」(食糧の統一買付け）を「定 購制」(契約買い付け）とし，リスクを農民に転嫁し たが，食糧不足時には，強制の指令制計画とし，直接 的に農民の利益をおびやかしたこと，また郷（鎮）政 府が担らはずの公共支出の負担を農民に転嫁したこと 等である．それ以外に注意すべき点として，政治体制 改革が経済体制改革よりはるかに遅れている現実があ げられる．いわゆる「村民自治組織」である村民委員 会とその幹部は, 真剣に農民利益の代表組織や代表者 となって扣らず，上級行政機関の指令に対する執行が 偏っているので, 彼らの農民との対立は不可避となっ ている.

次に, 幹部自身の行為不正がある. 既述のごとく幹 部が横領や収賄等といった方法によって集団・民息を 儀牲にして自己の利益を図るほか，農民の目に見兄る 他の多くの不正行為がある。例之ば，権力で家族を就 職させたり, 個人経営者に一般農民では得られない機 会や利益を提供すること，権力によってより広い住宅 地を獲得すること，高級住宅を建てること，公款で大 盤振舞や旅行等をすることがあげられる．1980年代に は, 横領, 収賄, 招宴等に対して, 上海市には近隣の 江蘇省や浙江省より厳しい制限があったため, 農村幹 部は少額の贈物でも極秘裡に受け取っていた．それが 今では, 「改革開放, 発展経済」の看板下で高額の賄 䀩む半ば公然とやりとりされるよらになっている. 当 然, その背景には幹部の不正行為を抑止するメカニズ ムが存在していないことがある.「一党体制」下で幹 部の不正行為に対する党内の監督制度が未整備である こと, 郷鎮企業の発展が集団経済の規模と実力を払大 させたが，集団資産の所有権が依然としてはっきりし ていない点がその原因として考兄られる.

\section{6. 結 語}

1980年代の高度経済成長により，唐家村のような都 市近郊農村は内陸部農村に比較して，かなり豊かにな った．しかし，市場メカニズムの導入に起因する農村
社会の変容や農民の階層分化，人民公社解体による基 層政府の農民に対する管理能力の低下，経済至上主義 による農村幹部に対する制度的な制約の弱体化等が原 因で，経済的に，順調に発展している農村地域に执い ても，各種の社会問題が発生している。そのらち，あ るものは市場化，近代化といら社会転換に伴う問題で あり，あるものは「伝統への回帰」といら問題である.

農民の視点から見ると, 社会問題の中で, 農民の日 常生活や経済利益に最も大きな影響を与えているのは 「社会風紀の悪化」であり，次は「賭博」であること が明らかにされた.これは政府, 学者, マスコミの関 心と大差がある. 後者が一貫して注目しているのは社 会秩序の破壊や不安定性を直接に引き起こす「刑事犯 罪」「幹部と農民との対立」「「民事紛争」等の問題で ある.

経済の急成長とともに農村の社会治安も悪化してき た．調查地である唐家村およびその周辺農村では，窃 盗, 横領・収賄, 賭博, 詐欺, 眨り合い等が主要な刑 事犯罪である．そのうち，農村の社会治安に最大の影 響を与えているのは「窃盗」である. 外来の出稼ぎ農 民の急増が窑盗犯罪の発生を増加させている。より注 意すべきは農民企業家を中心とした経済犯罪が深刻化 してきたことである。それによってもたらされる最大 の危害は，国家財産，集団財産，農民利益の着服とい った直接の影響ではなく，それが農村不安の誘発要因 になることにある.

1970年代末から，農村の民事紛争は主に農家の個人 利益と直接に関連する農家間の宅地紛争に集中してき た．それは1980年代の農村住宅建設ブームにより一層 深刻化してきた。

また，個人主義が激しく台頭してきた環境下で，農 村幹部に扣いて，「模範となっている」者が少なくな り，「仕事はまじめであるが，私利も図っている」者 が多くなってきた。アンケート調査から分かるよう に, 約 5 割の農民が幹部との関係が以前より悪くなっ たといら考学を持っている.ささらに近年，各種の負担 金徵収が重荷になり，幹部と農民間の経済格差も一層 払大したため，農民と幹部間の関係が以前より悪くな っていく傾向にある．その背景には現行の政策や制度 上の問題, および幹部自身の不正行為等がある.

唐家村やその周辺農村において, 経済発展に伴ら各 種の社会問題の多くが，伝統社会から近代社会へ，閉 鎖の集権社会から開放的市場化社会への転換過程にお いて発生したものである.農村の社会問題に対する緩 和と解決のため,「人治」の方式から如何にして「法 
治」の方式へ変革するか，これが経済発展中の農村の 重要な課題である.

\section{〈付記〉}

本稿は，筆者の「経済発展と農村社会問題」(石田 浩編著『中国伝統農村の变革と工業化』晃洋書店, 1996年）を加筆修正したものである，本稿を作成する にあって，関西大学経済学部の石田浩教授をはじめ, 日中共同研究グループの皆さんのお世話になった。ま た京都大学農学部の嘉田良平教授, 浅野耕太助手から は貴重な御助言とコメントをいただいた。ここに樑く 謝意を表します。

注 1）関西大学経済学部の石田浩氏を代表とする日中共同研 究グループ（日本側のメンバー「中国農村経済発展研 究会」の石田浩・川井悟・中田睦子・二宮一朗, 中国 側のメンバー謝自奮・莫建備・凌躍初・焦必方・筆 者）は文部省科研助成金によって，1988年 8 月 8 日〜 17 日と1989年 8 月 4 日〜 31 日に唐家村の 5 村民小組の 全体農家（222戸）を対象に，「中国伝統農村の工業化 と近代化」をテーマとして聞き取り調査とアンヶート 調査を実施した。ささらにその後関西大学学術研究助成 金によって，石田浩・莫建備の両氏は1993年10月 7 日 〜 8 日と1995年 8 月20日〜22日に唐家村 5 村民小組て 補足調査を行った。また筆者は1994年 6 月 8 日〜 11日 と1996年 6 月 12 日〜 16日に唐家村及び所属の奉賢県, 近隣の南匯県で資料調査を行った．本稿はこれらの調 査研究で入手した資料に基づくものである.

2）ここでの年龄別分類は，一般的に言えば，25歳以下㕌 は末婚者と結婚したばかりの者, 26-40歳層は子供が 成人になっていない者，41-50歳層は子供が就業して いるが，結婚していない者，51-65歳層は子供が結婚 している者であり，66歳以上層は高龄者ということに なる。

3）中生勝美「中国農村改革後の社会変化と矛盾」(石原 享一『中国経済の多重構造』, アジア経済研究所, 1991年) p.250. 宇野和夫「治安・犯罪」(中国研究所 『中国年鑑1994年版』）p.178.

4)「6害」はポルノ，売春, 婦女子の誘拐売買, 麻薬, 賭博, 封建的迷信を指す.

5）「四脚の幹部」は現在農村幹部の生活様式を指す。例 えば，朝に機関の自動車で通勤し，昼に公金で大盤振
舞し，夜にダンスホールに行くよらな生活のことであ る.「三要幹部」の糧は食糧を買付ける「定購糧」政 策を執行すること，銭は農家から現金を徽収するこ と，命は一人っ子の人口抑制政策を執行することを指 す.

6）文化大革命のときに徹底して排擊された祖先祭祀，民 間信仰，占い・風水の依頼，墳墓の修復等のいわゆる 「迷信活動」は，農村改革以降宗教の信仰に対する制 限が次第に緩和されてきたため，復活してきた。しか しいまなお，上海近郊農村では組織的宗教活動および 墳墓の復等は，前者が「一党支配体制」の安定性を 脅かし，後者が耕地の減少をもたらすので，依然とし て社会問題とされて厳格に取り締まられている.

7）奉賢県統計局『奉賢統計年鑑』1988年以降の各年版に 基づく.

8）奉賢県司法局の公告㯗に基づく.

9）南匯県統計局『南匯統計年鑑』1994年版と1995年版に 基づく.

10）南龨県公安機関の公告欗に基づく.

11）青村郷の郷営企業の雇用変化と唐家村の村営企業の雇 用变化については，王振「三中全会後の農村工業化と 産業構造の变化」(石田浩編著『中国伝統農村の变革 と工業化一上海近郊農村調査報告一』, 晃洋書店, 1996年）を参照.

12）奉賢県統計局『奉賢統計年鑑1994』と唐家村村民委員 会に基づく．ここでの流入した出稼ぎ労働者数は当地 で雇用されているものだけである．唐家村の場合，34 人は村営企業に雇用されており，3人は耕地の請負に よって雇用されている。

13）沙松「外地来㵧人員窃盗犯罪的特点分析」(『社会』, 1990年第10期）p.10亿よる

14）南龨県統計局『南陮統計年鑑』1994年版と1995年版に 基づく.

15）沙松，前揭論文，p.11.

16）農業部郷鎮企業司『郷鎮静企業統計資料』1989年から の各年版に基づく.

17）南陮県人民代表大会の工作報告（1995年）に基づく

18）「対農村紛紏現象的透視」(「社会」1991年第 3 期) p.21.

19）奉賢県統計局「奉賢統計年鑑」1991年からの各年版に 基づく.

20）王宗儒「危険的裂痕：農村党群関係疎離」(「社会」1990 年第 2 期) p.9-11.

（筆者：京都大学大学院農学研究科） 